\title{
Pendugaan Ragam Genetik dan Heritabilitas Karakter Hasil dan Komponen Hasil Tomat (Lycopersicum esculentum Mill.) di Dua Lokasi
}

\author{
Estimation of Genetic Variance and Heritability for Yield and Yield ComponenT \\ of Tomato (Lycopersicum esculentum Mill.) Across at Two Locations
}

\author{
Rudy Hermanto ${ }^{1}$, Muhamad Syukur ${ }^{2 *}$, dan Widodo ${ }^{3}$
}

Diterima 14 Desember 2016/Disetujui 22 Februari 2017

\begin{abstract}
The objective of the study was to determine the genetic variability and heritability for some characters of twenty tomato genotypes across at two locations. The experimental design used was Randomized Complete Block Design (RCBD), three replications as a block was nested in location (at two locations i.e Ciawi and Lembang). Plant materials were twenty genotypes: 42D, 50D, 96D, 61I, 40D, 21D, 59I, 57D, 40I, 102D, 58I, 59D, 94D, 43D, 60I, 99D, 100D, 98D, 04I dan Tora. Results indicated that time of harvest, fruit weight, number of fruit per plant, fruit length and fruit width had broad genetic variability. The characters of yield per plant and fruit firmness had narrow genetic variability. Broad-sense heritability was high for all observed characters. Genotype 42D can be used to develop high yielding tomato for small fruit size group, 59D and Tora for medium fruit size group, 97D and 94D for big fruit size group.
\end{abstract}

Keywords: broad, fruit, genetic, narrow, size, twenty

\begin{abstract}
ABSTRAK
Penelitian ini bertujuan untuk mendapatkan informasi keragaman genetik dan heritabilitas karakter hasil dan komponen hasil tomat (Lycopersicum esculentum Mill.) di dua lokasi. Percobaan dilakukan dengan menggunakan Rancangan Kelompok Lengkap Teracak (RKLT) dua faktor dengan tiga ulangan. Ulangan tersarang dalam lokasi (dua lokasi yaitu Ciawi dan Lembang). Materi genetik yang digunakan adalah 20 galur murni generasi F-7 yaitu 42D, 50D, 96D, 61I, 40D, 21D, 59I, 57D, 40I, 102D, 58I, 59D, 94D, 43D, 60I, 99D, 100D, 98D, 04I dan Tora. Keragaman genetik yang luas terdapat pada karakter umur panen, bobot buah, jumlah buah per tanaman, panjang buah dan diameter buah, sedangkan keragaman genetik sempit terdapat pada karakter bobot buah per tanaman dan kekerasan buah. Semua karakter yang diamati mempunyai nilai heritabilitas arti luas yang tinggi. Genotipe 42D dapat digunakan untuk mengembangkan varietas tomat berdaya hasil tinggi untuk kelompok ukuran buah kecil. Genotipe 59D dan Tora untuk kelompok ukuran buah sedang dan genotipe 97D dan 94D untuk kelompok ukuran buah besar.
\end{abstract}

Kata kunci: buah, dua puluh, genetik, luas, sempit, ukuran

\section{PENDAHULUAN}

Tomat (Lycopersicum esculentum Mill.) adalah salah satu jenis tanaman sayuran yang diproduksi dan dikonsumsi secara luas di dunia, baik dikonsumsi sebagai sayuran segar maupun untuk industri makanan olahan. Cina adalah negara produsen tomat terbesar di dunia disusul India, Amerika, Turki dan Mesir. Indonesia menempati urutan ke 21 produsen tomat di dunia (Pusat Data dan Sistem Informasi Pertanian, 2014) dengan luas tanam

${ }^{1}$ PT. BISI International Tbk.

J1. Kolonel Masturi No. 112, Desa Sukajaya, Kecamatan Lembang, Kabupaten Bandung Barat, Jawa Barat 40391, Indonesia

${ }^{2}$ Departemen Agronomi dan Hortikultura, Fakultas Pertanian, Institut Pertanian Bogor

J1. Meranti, Kampus IPB Darmaga 16680, Indonesia

${ }^{3}$ Departemen Proteksi Tanaman, Fakultas Pertanian, Institut Pertanian Bogor

Jl. Meranti, Kampus IPB Darmaga 16680, Indonesia

Email: muhsyukur@ipb.ac.id (*penulis korespondensi) 
54544 ha dan produksi $87 \quad 7792$ ton (Direktorat Jendral Hortikultura, 2016).

Budidaya tanaman tomat di Indonesia dilakukan oleh petani mulai dataran rendah sampai tinggi baik di Pulau Jawa maupun luar Pulau Jawa dengan luas tanam yang cenderung meningkat (Pusat Data dan Sistem Informasi Pertanian, 2014). Adanya peningkatan luas tanam menjadi prospek yang baik bagi penyediaan varietas tomat unggul. Varietas tomat unggul dapat dirakit melalui suatu program pemuliaan tanaman.

Sebelum menetapkan metode pemuliaan dan seleksi yang akan digunakan serta waktu seleksi, perlu diketahui tingkat keragaman genetik (Syukur et al., 2011). Keragaman genetik sangat mempengaruhi keberhasilan seleksi dalam program pemuliaan tanaman (Poehlman et al., 1995). Selain itu, perlu juga diketahui nilai heritabilitas karakter-karakter yang akan dijadikan target seleksi (Pinaria $e t$ al., 1995). Heritabilitas adalah parameter genetik yang digunakan untuk mengukur tingkat keterwarisan suatu karakter dalam populasi tanaman atau suatu pendugaan yang mengukur sejauh mana variabilitas penampilan suatu karakter dalam populasi yang disebabkan oleh peranan faktor genetik (Poehlman et al., 1995).

Beberapa penelitian tentang keragaman genetik dan heritabilitas pada tomat telah dilakukan oleh beberapa peneliti seperti Sutjahjo et al. (2015), Sajjan et al. (2016), Prajapati et al. (2015), Sajid et al. (2015) dan Mohamed et al. (2012), namun demikian belum memanfaatkan data interaksi genetik dan lingkungan dalam menduga parameter genetik. Penelitian ini bertujuan untuk mendapatkan informasi keragaman genetik dan heritabilitas karakter hasil dan komponen hasil tomat (Lycopersicum esculentum Mill.) di dua lokasi. Pemanfaatan informasi ragam genetik, ragam lingkungan dan ragam interaksi genetik dan lingkungan yang diperoleh dengan penanaman di dua lokasi untuk menduga keragaman genetik dan heritabilitas tomat, diharapkan dapat memperoleh hasil penelitian yang lebih baik dan lengkap jika dibandingkan dengan penanaman hanya di satu lokasi.

\section{BAHAN DAN METODE}

Penelitian berlangsung dari bulan Juni sampai Desember 2015 di Citapen, Ciawi (Kabupaten Bogor, Jawa Barat) dan Lembang (Kabupaten Bandung Barat, Jawa Barat). Citapen, Ciawi Bogor terletak pada ketinggian 650 meter di atas permukaan laut (m dpl), suhu rata-rata adalah 20.5-21.9 ${ }^{0} \mathrm{C}$, kelembaban udara sebesar $75-89 \%$ dan curah hujan sebanyak $219.8 \mathrm{~mm}^{\text {bulan }}{ }^{-1}$. Lembang, Bandung Barat, terletak pada ketinggian 1241 $\mathrm{m}$ dpl, suhu rata-rata $18.8-21.8{ }^{\circ} \mathrm{C}$, kelembaban udara 76-86\% dan curah hujan $162.5 \mathrm{~mm}$ bulan $^{-1}$ (BMKG, 2016).

Bahan tanaman yang digunakan 20 genotipe tomat yang terdiri atas 19 galur murni tomat koleksi PT. BISI International Tbk. yaitu 42D, 50D, 96D, 61I, 40D, 21D, 59I, 57D, 40I, 102D, 58I, 59D, 94D, 43D, 60I, 99D, 100D, 98D, 04I dan satu genotipe tomat komersial bersari bebas yang telah dilepas oleh Tim Pemuliaan Tomat Bagian Genetika dan Pemuliaan Tanaman, Departemen Agronomi dan Hortikultura Institut Pertanian Bogor, yaitu Tora.

Percobaan dilakukan dengan menggunakan Rancangan Kelompok Lengkap Teracak (RKLT) dua faktor dengan tiga ulangan. Ulangan tersarang dalam lokasi (dua lokasi yaitu Ciawi dan Lembang). Faktor pertama adalah 20 genotipe tomat dan faktor kedua adalah 2 lokasi percobaan yaitu: Ciawi dan Lembang. Setiap satuan percobaan terdiri dari 20 tanaman.

Teknik budidaya di kedua lokasi adalah penanaman di dalam rumah plastik (plastic house). Benih tomat disemaikan dahulu pada tray semai yang berisi media tanam steril sampai umur 3 minggu. Jarak tanam yang digunakan adalah 0.6 meter $\times 0.6$ meter. Penanaman di lokasi Ciawi menggunakan campuran media tanam yaitu arang sekam dan cocopeat (serbuk sabut kelapa) dengan perbandingan 1:1. Volume media tanam sebanyak $4 \mathrm{~kg}$ per polibag. Setelah pindah tanam setiap hari dilakukan penyiraman larutan pupuk $\mathrm{AB}$ Mix konsentrasi $2.8 \mathrm{~g} \mathrm{~L}^{-1}$ sebanyak $250 \mathrm{ml}$ pada fase vegetatif dan 500 $\mathrm{ml}$ pada fase generatif. Penanaman di lokasi Lembang dilakukan pada tanah langsung atau tidak menggunakan media tanam khusus. Komposisi pupuk yang digunakan adalah pupuk kandang $10000 \mathrm{~kg} \mathrm{ha}^{-1}$ dan pupuk 
dasar NPK $1400 \mathrm{~kg} \mathrm{ha}^{-1}$, ZA $350 \mathrm{~kg} \mathrm{ha}^{-1}$ serta kapur dolomit $2000 \mathrm{~kg} \mathrm{ha}^{-1}$ diberikan pada 10 hari sebelum tanam. Setelah pemberian pupuk kandang, pupuk dasar, dan kapur dolomit, bedengan ditutup dengan mulsa plastik hitam perak. Setelah penanaman setiap satu minggu sekali dilakukan irigasi dan penyemprotan pestisida berupa insektisida dan fungisida secara bergantian, dengan dosis sesuai anjuran. Pestisida yang digunakan adalah berbahan aktif imidakloprit, beta siflutrin, mankozeb, benomil dan polioksietilen alkil aril eter sebagai perekat. Pupuk susulan diberikan pada 4, 6 dan 8 minggu setelah tanam berupa larutan pupuk NPK konsentrasi $10 \mathrm{~g} \mathrm{~L}^{-1}$ dengan cara menyiram sebanyak $250 \mathrm{ml}$ tanaman $^{-1}$ pada lubang sejauh $8-10 \mathrm{~cm}$ dari pangkal batang tanaman. Peubah yang diamati adalah karakter hasil yaitu bobot buah per tanaman $(\mathrm{kg})$ dan karakter komponen hasil yaitu umur panen (hari setelah tanam), bobot buah (g), jumlah buah per tanaman (buah), panjang buah $(\mathrm{cm})$, diameter buah $(\mathrm{cm})$ dan kekerasan buah $\left(\mathrm{kgf} / \mathrm{cm}^{2}\right)$. Peubah yang diamati pada setiap genotipe dianalisis menggunakan analisis ragam gabungan. Interaksi genotipe $\mathrm{x}$ lingkungan (GxE) diperlukan pemulia untuk membantu proses identifikasi genotipe unggul. Analisis ragam gabungan untuk beberapa lokasi mengikuti model random yang disajikan pada Tabel 1 (Syukur et al., 2012).

Jika uji $\mathrm{F}$ berpengaruh nyata maka nilai tengah diuji lanjut dengan uji jarak berganda Duncan's Multiple Range Test (DMRT) pada taraf nyata $5 \%$. Analisis data ragam gabungan dan uji lanjut DMRT menggunakan fasilitas software SAS 9.13. Pendugaan parameter genetik meliputi pendugaan ragam genetik $\left(\sigma_{g}^{2}\right)$, ragam interaksi genetik $\mathrm{x}$ lingkungan $\left(\sigma_{\mathrm{gxe}}^{2}\right)$, ragam lingkungan $\left(\sigma_{\mathrm{e}}^{2}\right)$, ragam fenotipe $\left(\sigma_{\mathrm{p}}^{2}\right)$ (Hallauer dan Miranda, 1995) dan nilai koefisien keragaman genetik (KKG) diperoleh melalui:

$$
\begin{array}{ll}
\sigma_{\mathrm{g}}^{2} & =\left(\mathrm{M}_{3}-\mathrm{M}_{2}\right) / \mathrm{rl} \\
\sigma_{\mathrm{gxe}} & =\left(\mathrm{M}_{2}-\mathrm{M}_{1}\right) / \mathrm{r} \\
\sigma^{2}{ }_{\mathrm{e}} & =\mathrm{M}_{1} / \mathrm{rl} \\
\sigma_{\mathrm{p}}^{2} & =\sigma_{\mathrm{g}}^{2}+\sigma_{\mathrm{gxe}}^{2} / 1+\sigma^{2}{ }_{\mathrm{e}} \text { dan }
\end{array}
$$

$\mathrm{KKG}=\frac{\sqrt{\sigma^{2} \mathrm{~g}}}{\overline{\mathrm{x}}} \times 100 \%$

Luas atau sempitnya nilai keragaman genetik suatu karakter ditentukan berdasarkan ragam genetik dan standar deviasi ragam genetik menurut rumus berikut :

$\sigma_{\sigma \mathrm{g}}^{2}=\sqrt{\frac{2}{(r l)^{2}}\left[\frac{\mathrm{M}_{3}{ }^{2}}{d b_{g}+2}+\frac{\mathrm{M}_{2}{ }^{2}}{d b_{e}+2}\right]}$

bila:

$\sigma_{\mathrm{g}}^{2}>2 \sigma_{\sigma \mathrm{g}}^{2}$ : keragaman genetiknya luas,

$\sigma_{\mathrm{g}}^{2}<2 \sigma_{\sigma \mathrm{g}}^{2}$ : keragaman genetiknya sempit

(Pinaria et al., 1995).

Nilai dugaan heritabilitas $\left(\mathrm{h}^{2}\right)$ dalam arti luas (Poespodarsono, 1988) adalah:

$\mathrm{h}^{2}{ }_{\mathrm{bs}} \quad=\left(\sigma_{\mathrm{g}}^{2} / \sigma_{\mathrm{p}}^{2}\right) \times 100 \%$

$=\left(\sigma_{\mathrm{g}}^{2} /\left(\sigma_{\mathrm{g}}^{2}+\sigma_{\mathrm{gxe}}^{2} / 1+\sigma_{\mathrm{e}}^{2} / \mathrm{rl}\right)\right) \times 100 \%$

dimana :

$\sigma_{\mathrm{g}}^{2}=$ ragam genotipe, $\sigma_{\mathrm{gxe}}^{2}=$ ragam interaksi,

$\sigma_{\mathrm{e}}^{2}=$ ragam lingkungan, $\sigma_{\mathrm{p}}^{2}=$ ragam fenotipe

$\mathrm{r}=$ banyak ulangan, $\mathrm{l}=$ banyak lokasi .

Nilai heritabilitas diklasifikasikan sebagai berikut (Elrod dan Stansfield, 2002): rendah $=\mathrm{h}^{2}{ }_{\mathrm{bs}}<20 \%$, sedang $=20 \% \leq \mathrm{h}^{2}$ bs $<$ $50 \%$ dan tinggi $=\mathrm{h}_{\mathrm{bs}}^{2} \geq 50 \%$.

\section{HASIL DAN PEMBAHASAN}

Hasil analisis ragam gabungan menunjukkan bahwa lokasi berpengaruh sangat nyata terhadap peubah umur panen, bobot buah, dan kekerasan buah. Genotipe berpengaruh nyata terhadap peubah jumlah buah per tanaman dan sangat nyata terhadap umur panen, bobot buah, panjang buah, dan diameter buah. Interaksi antara genotipe dan lingkungan berpengaruh sangat nyata terhadap semua peubah yang diamati. Hasil ini menunjukkan bahwa daya hasil tomat lebih dipengaruhi oleh interaksi antara genotipe dan lingkungan daripada lingkungan dan atau genetik secara tunggal (Tabel 2 dan Tabel 3). Hal ini sejalan dengan hasil penelitian yang dilaporkan oleh Dewi (2015). 
Tabel 1. Analisis ragam gabungan di beberapa lokasi menggunakan model random

\begin{tabular}{llcll}
\hline Sumber Keragaman & $\mathrm{Db}$ & Kuadrat Tengah & Kuadrat Tengah Harapan & $\mathrm{F}_{\text {hit }}$ \\
\hline Lokasi & $(\mathrm{l}-1)$ & $\mathrm{M}_{5}$ & $\sigma^{2}+\mathrm{g} \sigma^{2} \mathrm{r} / \mathrm{l}+\mathrm{g} \mathrm{r} \sigma^{2} \mathrm{l}$ & $\mathrm{M}_{5} / \mathrm{M}_{4}$ \\
Ulangan/Lokasi & $\mathrm{l}(\mathrm{r}-1)$ & $\mathrm{M}_{4}$ & $\sigma^{2}+\mathrm{g} \sigma^{2} \mathrm{r} / 1$ & \\
Genotipe & $\mathrm{g}-1$ & $\mathrm{M}_{3}$ & $\sigma^{2}+\mathrm{r} \sigma^{2} \mathrm{gl}+\mathrm{rl} \sigma^{2} \mathrm{~g}$ & $\mathrm{M}_{3} / \mathrm{M}_{2}$ \\
Genotipe*Lokasi & $(\mathrm{g}-1)(1-1)$ & $\mathrm{M}_{2}$ & $\sigma^{2}+\mathrm{r} \sigma^{2} \mathrm{gl}$ & $\mathrm{M}_{2} / \mathrm{M}_{1}$ \\
Galat & $\mathrm{l}(\mathrm{g}-1)(\mathrm{r}-1)$ & $\mathrm{M}_{1}$ & $\sigma^{2}$ & \\
\hline
\end{tabular}

Keterangan: $\mathrm{l}=$ jumlah lokasi, $\mathrm{r}=$ jumlah ulangan, $\mathrm{g}=$ jumlah genotipe.

Berdasarkan Tabel 4 terlihat bahwa karakter bobot buah per tanaman dan kekerasan buah mempunyai keragaman yang sempit, sehingga seleksi terhadap karakterkarakter tersebut pada populasi yang diuji sudah tidak efektif. Peningkatan keragaman genetik perlu dilakukan dengan cara hibridisasi dengan populasi lain yang mempunyai hubungan genetik berbeda dengan populasi yang diuji. Sementara itu umur panen, bobot buah, jumlah buah per tanaman, panjang buah dan diameter buah mempunyai keragaman genetik yang luas. Seleksi berdasarkan karakter tersebut untuk populasi ini masih efektif. Beberapa penelitian pada tomat menunjukkan bahwa terdapat keragaman genetik yang luas untuk karakter umur panen (Jeany, 2016), bobot buah (Sutjahjo et al., 2015), jumlah buah per tanaman, diameter buah dan panjang buah (Ghosh et al., 2010).

Tabel 2. Kuadrat tengah analisis ragam gabungan karakter umur panen, bobot buah dan bobot buah per tanaman 20 genotipe tanaman tomat pada dua lokasi

\begin{tabular}{lcccc}
\hline \multirow{2}{*}{ Sumber Keragaman } & & \multicolumn{3}{c}{ Kuadarat Tengah } \\
\cline { 3 - 5 } & $\mathrm{db}$ & Umur Panen & Bobot Buah & $\begin{array}{c}\text { Bobot Buah per } \\
\text { Tanaman }\end{array}$ \\
\hline Lokasi & 1 & $24558.00^{* *}$ & $2940.11^{* *}$ & $0.13^{\text {tn }}$ \\
Ulangan/Lokasi & 4 & $19.00^{\text {tn }}$ & $65.93^{\text {tn }}$ & $1.02^{* *}$ \\
Genotipe & 19 & $264.61^{* *}$ & $2246.63^{* *}$ & $0.56^{\text {tn }}$ \\
Genotipe*Lokasi & 19 & $33.68^{* *}$ & $196.37^{* *}$ & $0.81^{* *}$ \\
Galat & 76 & 7.66 & 50.54 & 0.26 \\
\hline
\end{tabular}

Keterangan: *= berpengaruh nyata pada $\alpha=5 \%, * *=$ berpengaruh nyata pada $\alpha=1 \%, \mathrm{tn}=$ tidak nyata.

Tabel 3. Kuadrat tengah analisis ragam gabungan karakter jumlah buah per tanaman, panjang buah, diameter buah dan kekerasan buah 20 genotipe tanaman tomat pada dua lokasi

\begin{tabular}{lccccc}
\hline \multirow{2}{*}{ Sumber Keragaman } & & \multicolumn{4}{c}{ Kuadarat Tengah } \\
\cline { 3 - 6 } & $\mathrm{db}$ & $\begin{array}{c}\text { Jumlah Buah per } \\
\text { Tanaman }\end{array}$ & $\begin{array}{c}\text { Panjang } \\
\text { Buah }\end{array}$ & $\begin{array}{c}\text { Diameter } \\
\text { Buah }\end{array}$ & $\begin{array}{c}\text { Kekerasan } \\
\text { Buah }\end{array}$ \\
\hline Lokasi & 1 & $1013.29^{\text {tn }}$ & 0.06 tn & $0.42^{\text {tn }}$ & $6.50^{* *}$ \\
Ulangan/Lokasi & 4 & $385.52^{*}$ & $0.34^{*}$ & $0.14^{* *}$ & $0.14^{\text {tn }}$ \\
Genotipe & 19 & $1097.62^{*}$ & $4.34^{* *}$ & $1.41^{* *}$ & $0.44^{\text {tn }}$ \\
Genotipe*Lokasi & 19 & $386.09^{* *}$ & $0.31^{* *}$ & $0.15^{* *}$ & $0.36^{* *}$ \\
Galat & 76 & 153.28 & 0.10 & 0.04 & 0.15 \\
\hline
\end{tabular}

Keterangan: * berpengaruh nyata pada $\alpha=5 \%, * *=$ berpengaruh nyata pada $\alpha=1 \%, \mathrm{tn}=$ tidak nyata. 
Tabel 4. Koefisien keragaman genetik, ragam genetik dan standar deviasi ragam genetik beberapa karakter 20 genotipe tomat

\begin{tabular}{lrrrrl}
\hline \multicolumn{1}{c}{ Karakter } & $\begin{array}{r}\mathrm{KKG} \\
(\%)\end{array}$ & $\sigma_{\mathrm{g}}^{2}$ & $\sigma_{\sigma \mathrm{g}}{ }^{2}$ & $2 \sigma_{\sigma \mathrm{g}}{ }^{2}$ & Kriteria \\
\hline Umur panen & 7.45 & 38.49 & 13.64 & 27.28 & luas \\
Bobot buah & 25.47 & 341.71 & 115.67 & 231.35 & luas \\
Bobot buah per tanaman & 0.00 & -0.04 & 0.04 & 0.07 & sempit \\
Jumlah buah per tanaman & 22.08 & 118.59 & 57.39 & 114.78 & luas \\
Panjang buah & 15.22 & 0.67 & 0.22 & 0.45 & luas \\
Diameter buah & 9.84 & 0.21 & 0.07 & 0.15 & luas \\
Kekerasan buah & 6.13 & 0.01 & 0.03 & 0.05 & sempit \\
\hline
\end{tabular}

Keterangan: $\mathrm{KKG}=$ koefisien keragaman genetik, $\sigma_{\mathrm{g}}^{2}=$ ragam genetik, $\sigma_{\sigma \mathrm{g}}{ }^{2}=$ standar deviasi ragam genetik.

Keragaman genetik yang luas untuk beberapa karakter pada populasi ini disebabkan latar belakang genetik populasi yang berbeda dan seleksi akan diarahkan kepada karakter umur panen, bobot buah, jumlah buah per tanaman, panjang buah dan diameter buah. Pengetahuan tentang latar belakang genetik populasi sangat penting untuk memulai seleksi. Menurut Pinaria (1995), keragaman genetik suatu populasi tergantung pada latar belakang genetik segregan dan tingkat generasinya. Materi genetik dalam percobaan ini merupakan galur murni generasi F-7 yang sudah homozigot.

Nilai duga heritabilitas suatu karakter perlu diketahui karena bermanfaat untuk menduga kemajuan dari suatu seleksi dan untuk mengetahui bahwa karakter tersebut banyak dipengaruhi oleh faktor genetik atau lingkungan. Berdasarkan Tabel 5, semua karakter mempunyai nilai heritabilitas arti luas yang tinggi. Nilai heritabilitas yang tinggi untuk karakter tersebut menunjukkan bahwa pengaruh faktor genetik lebih besar dibandingkan faktor lingkungan dan memiliki peluang yang besar untuk dapat terwariskan kepada zuriatnya (Geleta et al., 2006).

Penelitian Madhukar et al. (2015) menunjukkan bahwa nilai duga heritabilitas yang tinggi pada karakter umur panen, bobot buah per tanaman, jumlah buah per tanaman, panjang buah dan diameter buah. Heritabilitas yang tinggi pada karakter bobot buah dan kekerasan buah masing-masing dilaporkan oleh Ravindra et al. (2015) dan Sajid et al. (2013). Mustafa et al. (2016) melaporkan nilai heritabilitas arti luas yang tinggi terjadi pada karakter panjang hipokotil, panjang dan lebar kotiledon.

Penanaman pada beberapa lokasi dapat menduga ragam interaksi genotipe $\mathrm{x}$ lingkungan
(Tabel 5) sehingga pendugaan ragam genetik akan lebih baik dibanding jika ditanam hanya pada satu lokasi, akan tetapi pendugaan ragam genetik akan lebih baik lagi jika populasi uji ditanam pada minimal dua lokasi dan dua musim sehingga interaksi genotipe $x$ lingkungan, genotipe $\mathrm{x}$ musim dan gentotipe $\mathrm{x}$ musim x lingkungan dapat dipisahkan (Baihaki, 2000). Keragaman genetik dan heritabilitas sangat bermanfaat dalam proses seleksi. Seleksi akan efektif jika populasi tersebut mempunyai keragaman genetik yang luas dan heritabilitas yang tinggi. Selain informasi ragam populasi, nilai tengah masing-masing genotipe juga berperan dalam efektivitas seleksi (Syukur, 2011).

Secara umum terdapat dua kategori buah tomat yaitu tomat sayur atau vegetable tomato dan tomat buah atau fruit tomato (Pusat Data dan Sistem Informasi Pertanian, 2014). Tomat sayur memiliki klasifikasi berdasar ukuran atau bobot buah yaitu ukuran kecil dengan bobot buah $<50 \mathrm{~g}$, sedang dengan bobot buah di atas 50 - $70 \mathrm{~g}$ dan besar dengan bobot buah $>70 \mathrm{~g}$ (Syukur et al., 2015). Buah tomat dengan ukuran kecil dan sedang banyak dijualbelikan di pasar-pasar tradisional dan pedagang sayur eceran, sedangkan buah tomat dengan ukuran besar banyak dijual belikan di pasar-pasar super market dengan harga yang lebih tinggi.

Berdasarkan informasi nilai tengah genotipe terdapat 5 genotipe yang dapat dikembangkan menjadi varietas tomat berdaya hasil tinggi masing-masing untuk kelompok tomat sayur dengan ukuran buah kecil yaitu genotipe 42D (bobot buah $48.16 \mathrm{~g}$; bobot buah per tanaman $2.35 \mathrm{~kg}$ ). Genotipe 59D (bobot buah $62.20 \mathrm{~g}$; bobot buah per tanaman $2.48 \mathrm{~kg}$ ) dan Tora (bobot buah $58.56 \mathrm{~g}$; bobot buah per tanaman $1.89 \mathrm{~kg}$ ) untuk kelompok 
ukuran buah sedang. Genotipe 97D (bobot buah $90.35 \mathrm{~g}$; bobot buah per tanaman 2.24 $\mathrm{kg}$ ) dan 94D (bobot buah $88.34 \mathrm{~g}$; bobot buah per tanaman $2.67 \mathrm{~kg}$ ) untuk kelompok ukuran buah besar (Tabel 6).

Tabel 5. Ragam galat, ragam interaksi genetik x lingkungan, ragam genetik, ragam fenotip, heritabilitas dan standar deviasi heritabilitas beberapa karakter 20 genotipe tomat pada dua lokasi

\begin{tabular}{lrrrrrrc}
\hline \multicolumn{1}{c}{ Karakter } & $\sigma_{\mathrm{e}}^{2}$ & $\sigma_{\mathrm{gxe}}^{2}$ & $\sigma_{\mathrm{g}}^{2}$ & \multicolumn{1}{c}{$\sigma_{\mathrm{p}}^{2}$} & $\mathrm{~h}_{\mathrm{BS}}^{2}$ & $\left.\sigma_{\mathrm{h}}{ }^{2}\right)$ & Kriteria \\
\hline Umur panen & 7.66 & 8.67 & 38.49 & 282.73 & 93.59 & 9.67 & tinggi \\
Bobot buah & 50.54 & 48.61 & 341.71 & 2353.24 & 95.47 & 9.77 & tinggi \\
Bobot per tanaman & 0.26 & 0.18 & -0.04 & 1.02 & 55.90 & 7.48 & tinggi \\
Jumlah buah per tanaman & 153.28 & 77.60 & 118.59 & 1316.22 & 83.39 & 9.13 & tinggi \\
Panjang buah & 0.10 & 0.07 & 0.67 & 4.52 & 96.15 & 9.81 & tinggi \\
Diameter buah & 0.04 & 0.04 & 0.21 & 1.50 & 94.32 & 9.71 & tinggi \\
Kekerasan buah & 0.15 & 0.07 & 0.01 & 0.66 & 68.24 & 8.26 & tinggi \\
\hline
\end{tabular}

Tabel 6. Nilai tengah karakter bobot buah dan bobot buah per tanaman 20 genotipe tomat pada dua lokasi

\begin{tabular}{|c|c|c|c|c|c|c|c|c|c|c|c|c|}
\hline \multirow{3}{*}{$\begin{array}{l}\text { Genotipe } \\
\text { 42 D }\end{array}$} & \multicolumn{6}{|c|}{ Bobot Buah (g) } & \multicolumn{4}{|c|}{ (Bobot Buah per Tanaman } & \multicolumn{2}{|c|}{$\left(\mathrm{kg} \operatorname{tanaman}^{-1}\right)$} \\
\hline & \multicolumn{2}{|c|}{ Lokasi 1} & \multicolumn{2}{|c|}{ Lokasi 2} & \multicolumn{2}{|c|}{ Rata-rata } & \multicolumn{2}{|c|}{ Lokasi 1} & \multicolumn{2}{|c|}{ Lokasi 2} & \multicolumn{2}{|c|}{ Rata-rata } \\
\hline & 40.76 & $\mathrm{~g}$ & 55.56 & ghij & 48.16 & $\mathrm{~g}$ & 2.46 & abcdef & 2.24 & abcd & 2.35 & abcd \\
\hline $50 \mathrm{D}$ & 55.94 & f & 64.94 & fgh & 60.44 & $\mathrm{f}$ & 2.06 & bcdef & 1.24 & d & 1.65 & de \\
\hline $96 \mathrm{D}$ & 66.71 & cdef & 59.35 & ghi & 63.03 & ef & 2.56 & abcd & 2.38 & abcd & 2.47 & abcd \\
\hline $61 \mathrm{I}$ & 57.36 & $\mathrm{f}$ & 81.74 & cde & 69.55 & e & 0.95 & $\mathrm{~g}$ & 2.32 & abcd & 1.63 & $\mathrm{e}$ \\
\hline TORA & 63.69 & def & 53.43 & hij & 58.56 & $\mathrm{f}$ & 2.09 & bcdef & 1.70 & bed & 1.89 & cde \\
\hline $40 \mathrm{D}$ & 77.75 & bc & 89.31 & bcd & 83.53 & d & 2.96 & $\mathrm{a}$ & 1.48 & $\mathrm{~cd}$ & 2.22 & abcde \\
\hline $21 \mathrm{D}$ & 27.80 & $\mathrm{~h}$ & 44.67 & $\mathrm{j}$ & 36.23 & $\mathrm{~h}$ & 1.96 & cdef & 2.98 & a & 2.47 & $a b c$ \\
\hline $59 \mathrm{I}$ & 70.41 & cdef & 92.25 & $\mathrm{bc}$ & 81.33 & d & 1.91 & def & 2.27 & abcd & 2.09 & abcde \\
\hline $97 \mathrm{D}$ & 92.01 & a & 88.68 & bcd & 90.35 & bcd & 2.37 & abcdef & 2.12 & abcd & 2.24 & abcde \\
\hline $40 \mathrm{I}$ & 94.55 & $\mathrm{a}$ & 93.62 & $\mathrm{bc}$ & 94.08 & bc & 2.60 & $a b c$ & 2.97 & $\mathrm{a}$ & 2.78 & $\mathrm{a}$ \\
\hline $102 \mathrm{D}$ & 69.15 & cde & 69.97 & efg & 69.56 & e & 2.50 & abcde & 2.44 & abcd & 2.47 & $a b c$ \\
\hline $58 \mathrm{I}$ & 71.68 & cde & 98.45 & $\mathrm{~b}$ & 85.07 & $\mathrm{~cd}$ & 1.79 & f & 2.77 & $\mathrm{ab}$ & 2.28 & abcde \\
\hline $59 \mathrm{D}$ & 60.55 & ef & 63.85 & fgh & 62.20 & ef & 2.69 & $a b$ & 2.27 & abcd & 2.48 & $a b c$ \\
\hline $94 \mathrm{D}$ & 87.48 & $a b$ & 89.21 & bcd & 88.34 & $\mathrm{~cd}$ & 2.65 & $\mathrm{ab}$ & 2.70 & $a b c$ & 2.67 & $\mathrm{ab}$ \\
\hline $43 \mathrm{D}$ & 31.88 & gh & 47.39 & $\mathrm{ij}$ & 39.63 & $\mathrm{~h}$ & 1.94 & cdef & 1.94 & abcd & 1.94 & cde \\
\hline $60 \mathrm{I}$ & 74.02 & $\mathrm{~cd}$ & 100.50 & $\mathrm{~b}$ & 87.26 & $\mathrm{~cd}$ & 2.06 & bcdef & 2.45 & abcd & 2.25 & abcde \\
\hline $99 \mathrm{D}$ & 96.28 & a & 99.95 & $\mathrm{~b}$ & 98.12 & $\mathrm{ab}$ & 2.32 & abcdef & 2.29 & abcd & 2.30 & abcde \\
\hline $100 \mathrm{D}$ & 65.82 & def & 74.94 & def & 70.38 & e & 2.32 & abcdef & 1.70 & bcd & 2.01 & bcde \\
\hline $98 \mathrm{D}$ & 55.39 & f & 64.07 & fgh & 59.73 & f & 2.94 & $\mathrm{a}$ & 1.42 & d & 2.18 & abcde \\
\hline $04 \mathrm{I}$ & 93.59 & $\mathrm{a}$ & 118.92 & $\mathrm{a}$ & 106.25 & $\mathrm{a}$ & 1.88 & ef & 1.99 & abcd & 1.94 & cde \\
\hline Rata-rata & 67.64 & & 77.54 & & 72.59 & & 2.25 & & 2.18 & & 2.22 & \\
\hline
\end{tabular}

Keterangan: Lokasi 1: Ciawi, Bogor. Lokasi 2: Lembang, Bandung Barat. Angka yang diikuti huruf yang sama pada kolom yang sama tidak berbeda nyata menurut DMRT taraf $5 \%$.

\section{KESIMPULAN}

Keragaman genetik yang luas terdapat pada karakter umur panen, bobot buah, jumlah buah per tanaman, panjang buah dan diameter buah, sedangkan keragaman genetik sempit terdapat terdapat pada karakter bobot buah per tanaman dan kekerasan buah. Semua karakter yang diamati mempunyai nilai heritabilitas arti luas yang tinggi. Genotipe 42D dapat digunakan untuk mengembangkan varietas tomat berdaya hasil tinggi untuk kelompok tomat sayur dengan ukuran buah kecil. Genotipe 59D dan Tora untuk kelompok ukuran buah sedang dan genotipe 97D dan 94D untuk kelompok ukuran buah besar.

\section{DAFTAR PUSTAKA}

Baihaki, A. 2000. Teknik Rancang dan Analisis Penelitian Pemuliaan. Fakultas Pertanian Universitas Padjadjaran. Bandung. 
[BMKG] Badan Metereorologi Klimatologi dan Geofisika Stasiun Klimatologi Dramaga Bogor. 2016. Data Iklim Bulanan Tahun 2015.

Dewi, S.M., Sobir, M. Syukur. 2015. Interaksi genotipe $\mathrm{x}$ lingkungan hasil dan komponen hasil 14 genotipe tomat di empat lingkungan dataran rendah. J. Agron. Indonesia. 43(1): 59-65.

Direktorat Jendral Hortikultura. 2016. Produksi, luas panen dan produktivitas sayuran di di Indonesia tahun 2015. http://www.pertanian.go.id/Indikator/ta bel-2-prod-lspn-prodvitashorti-pdf. [4 November 2016].

Elrod, S.L, W.D. Stansfield. 2002. Schaum's Outline of Theory and Problems of Genetics, 4th ed. Mc Graw-Hill. New York.

Geleta, F.L., T.M. Labuschagne. 2006. Combining ability and heritability for vitamin $\mathrm{C}$ and total soluble solids in pepper (Capsicum annuum L.). J. Sci. Food Agric. 86(9): 1317-1320.

Ghosh, K.P., A.K.M.A. Islam, M.A.K. Mian, M.M. Hossain. 2010. Variability and character association in F2 segregating population of different commercial hybrids of tomato (Solanum lycopersicum L.). J. Appl. Sci. Environ. Manage. 14(2): 91-95.

Hallauer, A.R., J.B. Miranda. 1995. Quantitative Genetics in Maize Breeding $2^{\text {nd }}$ Edition. Iowa State Univ Press. Iowa.

Jeany, E.W., Y. Izmi, S. Darmawan. 2016. Heritabilitas dan kemajuan genetik harapan empat populasi F2 tomat (Lycopersicum esculentum Mill.) pada budidaya organik. J. Produksi Tanaman. 4(5): 361-369.

Madhukar, S.P., S. Nirinijan, K. Anil, M.K. Singh, G.C. Yadav, B.G. Mahesh. 2015. Genetic variability, heritability and genetic advance of growth and yield components of tomato (Lycopersicon esculentum M.). Environment \& Ecology. 33(3): 1034-1037.

Mohamed, S.M., E.E. Ali, T.Y. Mohamed. 2012. Study of heritability and genetic variability among different plant and fruit characters of tomato (Solanum lycopersicon L.). Intl. J. Sci. Tech. Res. 1(2): 55-58.

Mustafa, M., M. Syukur. S.H. Sutjahjo, Sobir. 2016. Pewarisan Karakter Kualitatif dan Kuantitatif pada Hipokotil dan Kotiledon Tomat (Solanum lycopersicum L.) Silangan IPB T64 x IPB T3. J. Hort. Indonesia. 7(3): 155-164.

Pinaria, A., A. Baihaki, R. Setiamihardja, A.A. Daradjat. 1995. Variabilitas genetik dan heritabilitas karakter-karakter biomassa 53 genotipe kedelai. Zuriat. 6(2): 88-92.

Poehlman, J.M., D.A. Sleeper. 1995. Breeding Field Crops. Iowa State University Press. USA.

Poespodarsono, S. 1988. Dasar-dasar Ilmu Pemuliaan Tanaman. PAU. Bogor.

Prajapati, S., A. Tiwari, S. Kadwey, T. Jamkar. 2015. Genetic variability, heritability and genetic advance in tomato (Solanum Lycopersicon Mill.). Intl. J. Agric. Env. Biotech. 8(2): 245251.

Pusat Data dan Sistem Informasi Pertanian. 2014. Outlook komoditi tomat. http://pusdatin.setjen.pertanian.go.id/tin ymcpuk/gambar/file/tomat2014.pdf. [4 November 2016].

Ravindra, K., S.K. Singh, K. Srivastava, R.K. Singh. 2015. Genetic variability and character association for yield and quality traits in tomato (Lycopersicon esculentum Mill). Agriways. 3(1): 31-36.

Sajjan, A.M., H.B. Lingaiah, B. Fakrudin. 2016. Studies on genetic variability, heritability and genetic advance for yield and quality traits in tomato (Solanum lycopersicum L.). Intl. J. Hort. 6(18): 1-3. 
Sajid, S., M.A. Faqir, N. Ghulam, Q. Iqbal. 2015. Estimation of heritability and genetic advance for some characters related to earliness in tomato (Solanum lycopersicum L.). J. Agric. Res. 53(3): 351-356.

Sajid, S., M.A. Faqir, N. Ghulam, Q. Iqbal, M. M. Raza, M. Saleem. 2013. Heritability studies of fruit related traits in Solanum lycopersicum L. germplasm. J. Biol. Life Sci. 4(2): 56-62.

Sutjahjo, S.H., C. Herison, Sulastrini, Marwiyah. 2015. Pendugaan keragaman genetik beberapa karakter pertumbuhan dan hasil pada 30 genotipe tomat lokal. J. Hort. 25(4): 304-310.

Syukur, M., S. Sujiprihati, R. Yunianti. 2012. Teknik Pemuliaan Tanaman. Penebar Swadaya. Jakarta.

Syukur, M., Helfi, E.S., R. Hermanto. 2015. Bertanam Tomat di Musim Hujan. Penebar Swadaya. Jakarta.

Syukur, M., S. Sujiprihati, R. Yunianti, D.A. Kusumah. 2011. Pendugaan ragam genetik, dan heritabilitas karakter komponen hasil beberapa genotipe cabai. J. Agrivigor. 10(2): 148-156. 